\title{
MASCULINIDADE, CONFLITOS E SOLIDARIEDADES NO MUNDO DO TRABALHO FERROVIÁRIO NA ARGENTINA (1912-1917)*
}

\author{
Silvana Alejandra Palermo**
}

\begin{abstract}
Resumo:Tomando o conceito de gênero como categoria de análise, este artigo indaga sobre o ideal de masculinidade articulado e inculcado por um dos mais importantes sindicatos ferroviários na Argentina, la Federación Obrera Ferrocarrilera, desde sua fundação, em 1912, até a primeira greve geral em 1917. Concentra-se na correspondência dos ferroviários com o periódico sindical, para examinar suas noções de honra e respeitabilidade, sua aceitação do modelo de paternidade responsável e de homem capaz de assegurar o sustento econômico de sua família, e a apelação aos vínculos masculinos para fortalecer a solidariedade no mundo do trabalho. Deste modo, este estudo espera contribuir para as pesquisas recentes sobre trabalhadores e masculinidade na América Latina, um aspectos ainda pouco pesquisados nas relações de gênero na região.
\end{abstract}

Palavras-chave: masculinidade, história dos trabalhadores, ferroviários.

Abstract: By taking gender as a concept of analysis, this article explores masculine ideals articulated and inculcated by one of the most important railroad union in Argentina, la Federación Obrera Ferrocarrilera, from its origins in 1912 until the first railroad general strike in 1917. It concentrates on railroaders' correspondence to the union journal to examine working class notions of honor and respectability, their adherence to paternal responsibility and the breadwinner ideology and their appeal to male bonds and fraternity to strengthen solidarity at the workplace. In so doing, this article seeks to contribute to current studies on working class masculinity in Latin America, still one of the least research topics of gender relations in the region.

Key words: masculinity, working class history, railroad workers.

\section{“CARTAS DE PROTESTO": HISTÓRIAS COTIDIANAS NO PERIÓDICO SINDICAL}

Nos últimos anos, os estudos de gênero que têm concentrado sua atenção na identidade sexual dos trabalhadores destacam o mundo do trabalho como um espaço central para a construção da identidade masculina. Problemáticas que estiveram

\footnotetext{
* Tradução: Márcia C. de Oliveira Cury e Vinícius de Rezende. Revisão: Cristiana Schettini e Fabiane Popinigis.

** Docente-pesquisadora do Instituto de Ciencias, Universidad Nacional de General Sarmiento (UNGS), Argentina. Contato: sapalermo@ungs.edu.ar. Este trabalho foi possível graças a uma Bolsa de estudos de Reinserção do CONICET e da Fundación Antorchas. Integra meu projeto de pesquisa "La formación de La elite obrera en La Argentina: clase, género y ciudadanía en el mundo ferroviario (1890-1940)". Uma versão preliminar foi apresentada na "V Jornadas Nacionales: Espacio Memoria Identidad", Rosario, Outubro de 2008, na seção "Género, cultura y sociedad en América Latina, siglos XIX y XX." Agradeço às coordenadoras Valeria Pita e Cristiana Schettini, assim como à comentadora María Celia Bravo por suas valiosas sugestões.
} 
estritamente vinculadas às indagações sobre o trabalho feminino - a sexualidade, a reprodução, o trabalho e o corpo - são incorporadas, de maneira crescente, às investigações sobre a classe operária masculina. A historiografia latino-americana não esteve alheia a esta tendência. Como exemplo, basta mencionar a centralidade que os trabalhos de Fernando Teixeira da Silva, sobre os portuários de Santos, ou os de Thomas Klubbock, sobre os mineiros no Chile, atribuíram à força física, à coragem e à virilidade como componentes essenciais na cultura do trabalho, como elementos chave do repertório simbólico que contribuem para a construção de lideranças sindicais e estruturam relações de resistência e solidariedade no mundo do trabalho. ${ }^{1}$ A questão da capacidade e resistência física como atributo constitutivo da identidade do homem trabalhador representa, pois, uma das temáticas privilegiadas da agenda de pesquisas recentes. Junto a tal temática, como assinalou a historiadora Ava Baron, emergem outras questões, em grande medida vinculadas à anterior. Em primeiro lugar, as "crises" ou "ameaças" à masculinidade, uma questão que se refere às respostas dos trabalhadores frente às conjunturas ou contextos que dificultam o cumprimento das regras e ideais de masculinidade, os levam a um esforço de reconstruir uma identidade sexual que percebem como ameaçada. Por outro lado, os historiadores têm explorado criticamente a construção da irmandade e solidariedade masculina, atentando para a construção de vínculos, laços e relações entre homens gestados, em particular, em espaços de sociabilidade masculinos, que nutriram e sustentaram a criação de organizações e ações coletivas dos trabalhadores. ${ }^{2}$

Este estudo se propõe a explorar o ideal de masculinidade promovido por um dos principais sindicatos ferroviários da Argentina, a Federación Obrera Ferrocarrilera (FOF), uma organização que, desde 1912, representou a todos os trabalhadores de tráfego, oficinas, trilhos e obras das ferrovias. Com este fim focalizaremos as problemáticas antes mencionadas: por um lado, o modo pelo qual os trabalhadores reagiram frente às ansiedades geradas pelo dever de cumprir com o modelo de

1 SILVA, Fernando Teixeira da. "Valentia e cultura do trabalho na estiva de Santos." In: BATALHA, Claudio H. M. (et. al.) Culturas de Classe. Campinas; Editora Unicamp, 2004, p. 205-245; KLUBBOCK, Thomas. Contested Communities. Class, Gender and Politics in Chile's El Teniente Copper Mine, 19041951. Durham: Duke University Press, 1998.

2 BARON, Ava. "Masculinity, the Embodied Male Worker, and the Historian's Gaze". International Labor and Working Class History, n. 69, 2006, p. 143-160. 
homem trabalhador capaz de assegurar o sustento de sua família; por outro, as formas pelas quais se procurava desenvolver vínculos fraternais que, apelando à solidariedade masculina no cotidiano de trabalho, construíam e fortaleciam a organização sindical dos trabalhadores ferroviários.

O quinquênio transcorrido da fundação da Federación Obrera Ferrocarrilera, em 1912, até a explosão da primeira greve geral ferroviária, em 1917, constitui um período privilegiado para abordar tais temáticas. Com efeito, trata-se de anos difíceis e incertos para os trabalhadores e suas famílias, devido à recessão causada pelo impacto negativo da Primeira Guerra Mundial na economia argentina. No começo do século XX, por tratar-se de grandes empresas na vanguarda da inovação empresarial e tecnológica em franca expansão, as companhias ferroviárias se transformaram numa atrativa fonte de emprego para homens de diferentes idades e qualificações, capazes de oferecer salários relativamente altos, possibilidades de capacitação e ascensão profissional e, inclusive, uma série de benefícios extra-salariais para o trabalhador e sua família. No entanto, no contexto de recessão provocado pela guerra, estas expectativas não apenas tornaram-se ilusórias, como também deram uma guinada de cento e oitenta graus: ameaças de desemprego, redução salarial, limitações das ascensões e reduções dos benefícios extra-salariais. Não obstante, à medida que as circunstâncias econômicas se deterioravam, a vida política se reanimava graças à aprovação da lei Sáenz Peña, em 1912, que garantiu aos homens o direito ao voto secreto sem restrições e estimulou as autoridades políticas a assegurar eleições limpas, sem fraude. Nesta conjuntura, a atividade sindical também se recuperou. Prova disso foi a fundação da Federación Obrera Ferrocarrilera, que retomou a tarefa de organizar todos os trabalhadores ferroviários sem distinção de ofícios - com exceção dos maquinistas e foguistas, representados pelo sindicato La Fraternidad - e que seria protagonista da primeira greve geral ferroviária do país, ocorrida entre fins de setembro e outubro de 1917.

Apenas organizada, a FOF lançou seu periódico El Obrero Ferroviário (EOF), uma publicação mensal que dedicava várias páginas a informar, entre outras questões, sobre a atividade sindical nas empresas e os problemas no mundo do trabalho. Esta seção, denominada "movimento e informes das seções" ou "a organização e as empresas", se nutria de notícias provenientes de dois tipos de fontes: os informes 
escritos pelos representantes sindicais, cujas colunas no periódico se encerravam com a assinatura "correspondentes", e as cartas enviadas por trabalhadores, no geral assinadas com pseudônimos. Em sua grande maioria, estas "cartas de protesto" relatavam episódios de conflitos cotidianos entre trabalhadores, seus chefes e capatazes, elogiavam as iniciativas e condutas de trabalhadores comprometidos com o sindicato ou denunciavam o comportamento daqueles que rejeitavam ou boicotavam a organização. Os episódios relatados nestas cartas e a linguagem utilizada pelos trabalhadores para articular suas demandas oferecem informações úteis e ainda pouco exploradas para dar conta das tensões, conflitos e, inclusive, violências num mundo de trabalho masculino. Pode-se argumentar que o ideal de trabalhador ferroviário, ao qual estes trabalhadores aspiravam, e que sentiam estar sendo ameaçado pelo contexto de crise, assim como o modelo de "operário consciente", que demonstram os informes e as cartas publicadas em EOF, revelam noções compartilhadas sobre a honorabilidade masculina e os deveres e direitos de um homem trabalhador. Os informes das seções e as "cartas de protesto" também oferecem indícios para se compreender como se construíam vínculos a partir de códigos e práticas de sociabilidade entre homens de diferentes idades. Em suma, sobre a base desta mostra documental, este artigo analisará a partir de uma perspectiva de gênero os conflitos cotidianos no mundo do trabalho ferroviário e a solidariedade de classe promovida pela FOF. Procuramos, assim, recuperar a identidade social dos trabalhadores como uma identidade sexuada e desvelar o modo pelo qual as noções sobre a diferença sexual estruturaram as resistências a seus superiores, informaram seus temores e ansiedades ante a dificuldade de ajustar-se ao papel de provedor de suas famílias e serviram de sustentação aos apelos de unidade entre os próprios trabalhadores.

\section{A MASCULINIDADE DESAFIADA: MANTER O LAR E DEFENDER A HONRA EM TEMPOS DE CRISE}

Que a recessão de meados da década de 1910 tornou cada vez mais difícil para os trabalhadores ferroviários cumprir com as obrigações que o modelo dominante de homem chefe de família estabelecia era um fato publicamente reconhecido, inclusive 
pelas autoridades. É particularmente revelador nesse sentido o informe que o Dr. Alejandro Ruzo, funcionário do Departamento Nacional do Trabalho, apresentou ao Ministério de Obras Públicas a propósito da paralisação na Ferrocarril Central Argentina em agosto de 1917, um mês antes de estourar a greve geral. Este funcionário admitia que os trabalhadores se solidarizavam com Polizzi e Fernandez os homens acusados de liderar o conflito, segundo a gerência - por tratar-se de uma demissão injustificada de dois artesãos de "ofício", com anos de experiência na oficina. Sustentava que, a partir da perspectiva dos trabalhadores, a qualificação e o tempo de serviço eram direitos que a chefia deveria respeitar e enfatizou que se tratava ademais de esmerados chefes de família, um ideal com o qual os trabalhadores pareciam se identificar. Para descrever as aflições de Polizzi, Ruzo não necessitava mais do que mencionar que ganhava "um salário de 35 centavos por hora e mantém a sua esposa e sete filhos." ${ }^{3}$ Há que se recordar que durante a crise econômica o salário dos oficiais das oficinas reduziu-se à metade, mesmo o daqueles mais qualificados que enfrentavam menor concorrência, com o qual as angústias sobre a manutenção do lar constituíam um motivo de preocupação cotidiana para os ferroviários.

O efeito negativo da racionalização empresarial sobre as famílias dos trabalhadores viu-se reforçado pela falta de trabalho que afetava aos demais membros do lar. Ruzo apontava que as mulheres das famílias ferroviárias não conseguiam encontrar ocupação em zonas afastadas ou em povoados ferroviários, de modo que todo o peso do sustento familiar descansava nos ganhos do trabalhador. ${ }^{4}$ Tampouco se vislumbravam boas perspectivas de trabalho para os jovens. Mesmo quando as ferrovias e, em especial, as grandes oficinas ferroviárias, demandavam mão-de-obra masculina, as possibilidades de promoção se viam limitadas devido à crise. $\mathrm{O}$ informe de Ruzzo assinalava com preocupação que a Ferrocarril Central pagava muito pouco aos quinhentos meninos que empregava como aprendizes e, o que era pior, ainda não havia promovido nenhum deles após três anos de trabalho. Não é casual então que a situação dos aprendizes e sua educação tenham ocupado boa parte dos debates nas assembléias sindicais e que estas tenham atraído a participação da população jovem. De fato, esta questão apareceu contemplada na lista de demandas apresentada pelos 
trabalhadores das oficinas da Central Argentina à administração. Ainda que os homens adultos com um ofício tenham buscado proteger-se da concorrência dos menores pediram que não se contratasse menores de 16 anos -, buscaram ao mesmo tempo assegurar um futuro laboral para seus familiares homens, solicitando que, após o quinto ano de trabalho, todos os aprendizes fossem elevados a oficiais. ${ }^{5} \mathrm{~A}$ razão por trás desta demanda é evidente: conforme os ganhos dos homens se reduziam e as famílias dificilmente podiam aumentar seus ganhos com o trabalho dos demais membros do lar, os gastos em produtos de primeira necessidade e os aluguéis aumentavam por causa da inflação. Por sua vez, a carestia havia disparado os gastos das famílias trabalhadoras em matéria de saúde, habitação e alimentos. A situação dos lares não podia ser mais urgente.

Em tal conjuntura econômica, as ansiedades e temores dos trabalhadores em relação ao cumprimento de suas obrigações como provedores da segurança familiar se intensificaram. Mais ainda, como se objetiva demonstrar aqui, pareciam também desmoronar-se as expectativas de realização individual, respeitabilidade e honorabilidade masculinas associadas a um emprego em empresas que se supunham tecnologicamente inovadoras e rentáveis. O reconhecimento da lacuna entre uma modernidade teórica e um mundo do trabalho empobrecido e arbitrário constituía um tópico recorrente nas cartas enviadas ao jornal sindical. O tom de desilusão e desengano que transparecia nas cartas transmitia a distância entre as aspirações dos trabalhadores e suas vivências cotidianas em empresas comprometidas pela crise e caracterizadas por uma profunda opacidade nas regras que regulavam o acesso ao trabalho, as ascensões e os padrões disciplinares. Ao ingressarem numa empresa ferroviária, os homens esperavam uma apreciação justa de suas qualificações e das tarefas que desempenhavam. A desnaturalização das mesmas e a atribuição de atividades que pouco tinham a ver com seus ofícios ou suas aspirações laborais eram motivos recorrentes de críticas às chefias. Este é o caso de um informe sobre os problemas do pessoal de pátio e dos cambistas na Ferrocarril Midland, o qual assinalava que alguns chefes os obrigavam a realizar trabalhos que

5 La Prensa, 23/9/1917. 
Nada têm a ver com sua índole de ferroviários; assim podem ser vistos arrumando o "sitiozinho", o "jardinzinho" do chefe, outro afazer de caráter "doméstico", tal como servir de mensageiro, indo ao armazém quantas vezes for necessário para a casa do chefinho ${ }^{*}{ }^{6}$

Como se pode ver, ser empregado para o serviço "doméstico" era percebido como afronta tanto às qualificações laborais de um trabalhador ferroviário como à sua identidade sexual masculina. Enquanto as tarefas do lar constituíam um trabalho qualificado como "naturalmente" feminino, o trabalho de um ferroviário era concebido como "naturalmente" masculino. Daí que as tarefas de um peão da estação Libertad, que passava boa parte de seu tempo "varrendo a cozinha, rachando lenha, regando as plantas da 'chefa' ou lavando as panelas" e, inclusive, até o viam peregrinar "buscando água quente para preparar o banho morno da "chefa", tenham sido descritas em tom trágico. ${ }^{7}$ Da perspectiva dos trabalhadores homens, este operário havia ficado exposto a uma dupla humilhação: fazer um trabalho de mulheres e ficar subordinado às ordens de uma mulher, uma situação dificilmente imaginável e tolerável para um jovem que ingressava no trabalho ferroviário.

Como boa parte do pessoal ferroviário realizava tarefas que o expunha ao contato cotidiano com o público, os regulamentos das empresas estabeleciam estritas normas de etiqueta, de conduta e indumentária do pessoal. Não obstante, a crise que produziu a Primeira Guerra Mundial sobre a economia argentina forçou as companhias a reduzirem seus gastos, o que produziu desemprego, jornadas e tarefas mais intensas, diminuição salarial e uma deterioração geral das condições de trabalho. Para os trabalhadores, isto implicou, em certas ocasiões, um ostensivo menosprezo à sua dignidade pessoal. Para ilustrar isso, também a partir da estação Libertad da Ferrocarril Midland, explicava-se que alguns guardas eram designados ao serviço de um "senhor qualquer" e um "faroleiro" podia ficar encarregado do trem de passageiros "de quem, só de ver sua humilde indumentária, a empresa deveria sentir-se envergonhada." ${ }^{8}$ Esta vergonha se deslocava, sem dúvida, ao próprio trabalhador, uma vez que este era exposto à exibição pública, aparecendo com o mesmo traje daqueles que desempenhavam um ofício não qualificado. Ainda que o uso do uniforme fosse uma

\footnotetext{
Jefezuelo: termo pejorativo para referir-se ao chefe. [Nota dos tradutores] El Obrero Ferroviario [EOF], Libertad (FC Midland), Agosto, 1916, n. 39, p.3. EOF, Libertad (FC Midland), Diciembre 1916, n.43, p. 3.

EOF, Agosto 1916, n. 39, p. 3.
} 
das obrigações impostas pelas gerências, servia às vezes como marca de distinção entre os trabalhadores, já que tornava visíveis as hierarquias no interior das companhias ferroviárias. Uma carta assinada por alguém denominado "o viajante" denunciava a Companhia Geral por ficar com os uniformes dos guardas e fazê-los passar o inverno com o traje de verão, concluindo que "os garis municipais estão melhor que os guardas da Companhia Geral." ${ }^{9}$ Um homem que ingressava nos trabalhos de uma companhia ferroviária almejava participar de uma comunidade ocupacional que gozasse de certo reconhecimento, status, privilégios e um tratamento diferenciado do recebido pelos trabalhadores de setores tecnologicamente menos inovadores, oficinas pequenas ou atividades consideradas não qualificadas. Inclusive, a suposição de que as relações de trabalho nestas grandes e modernas empresas assemelhavam-se ao trabalho rural provocava rejeição. Um informe proveniente das Oficinas Aliança, da Ferrocarril Pacífico, expressava sua indignação, afirmando que "Nosso tratamento é pior do que se usa com os trabalhadores nos obrajes del Chaco ${ }^{*} !{ }^{\prime 10}$

Deve-se sublinhar que a culpa pela deterioração das condições de trabalho era atribuída mais às chefias do que às condições desfavoráveis criadas pela recessão. As tensões e conflitos trabalhistas sugerem não só uma disputa em torno dos efeitos da crise e da racionalização empresarial, como também um clima geral de impugnação ética aos chefes, supervisores e capatazes. Foi em torno de seus abusos e arbitrariedades que os trabalhadores centraram suas denúncias. Esta condenação moral originava-se de uma experiência diária de arbitrariedade e discriminação. Podese argumentar que o descontentamento manifestava uma crise de deferência e traduzia uma aspiração generalizada de democratização das relações entre trabalhadores e superiores no mundo do trabalho. Não é casual que as cartas e informes publicados no EOF retratem os abusos dos chefes e capatazes nos mínimos detalhes. De fato, para além das importantes diferenças que separavam os gerentes dos supervisores de menor hierarquia, uma das qualidades que os unia era suas

\footnotetext{
9 EOF, “La Cía. Gral. es un desquicio”, Septiembre 1916, n. 40, p. 3.

* Obrajes maderos del Chaco eram estabelecimentos voltados à exploração de madeira nas zonas rurais da região do Gran Chaco, noroeste da Argentina. Eram conhecidos pelas duras condições de trabalho, maus-tratos sofridos por trabalhadores e baixos salários. [Nota dos tradutores]

10 EOF, FCP, Alianza, junio de 1914, n. 21.
} 
tendências "despóticas". A elas aludiam no geral os apelidos que os trabalhadores punham em seus superiores: "Kaiser", "Alfonso XIII", "caciques", "Torquemadas" ou "pequenos Torquemadas"

Não obstante, é necessário notar que parecia existir um tratamento mais considerado para com os chefes do que para com os capatazes, na medida em que se aceitava, tácita ou explicitamente, que aqueles contavam com saberes e conhecimentos que os próprios trabalhadores valorizavam. Inclusive quando eram utilizados contra eles. Referindo-se às intenções dos chefes de limitar o crescimento da organização sindical nas oficinas da Ferrocarril Británico Sud, um trabalhador explicava que "os 'mister' que tudo prevêem, não deixavam de notar que a organização das Oficinas vinha se fortificando, cada dia mais altiva e mais potente"; portanto, ordenaram aos capatazes que destruíssem os baldes que os trabalhadores utilizavam para assearem-se, como forma de "sabotagem"". ${ }^{11}$ A precaução, uma qualidade imprescindível para dirigir um serviço de maneira segura e regular, não era aqui condenada como tal, mas sim quando se colocava a serviço da repressão das organizações operárias.

Percebe-se ainda que a respeitosa distância e a atribuição de certos traços positivos à chefia das empresas ferroviárias dos pampas associava-se à origem européia de seus chefes, em sua maioria britânicos ou franceses. Assim evidencia a carta assinada sob o pseudônimo "sacristão com rabo". Esta informava que na ferrovia de Rosário a Puerto Belgrano a maioria dos empregados tinha expectativas favoráveis a respeito da nova administração, pois "segundo diz a gente, os ingleses trabalham de acordo com a justiça." Não obstante, quando os programas de racionalização provocaram a redução de pessoal, reconheceram seu equívoco:

hoje nos damos conta de que incorríamos num erro. Os burgueses ingleses são como todos: exploram e tiranizam aos montes [...] Se na Inglaterra se goza de algum bem estar, a quem se deve? À classe trabalhadora que vai despertando da letargia. ${ }^{12}$

\footnotetext{
Referência a Tomás de Torquemada, monge dominicano nomeado primeiro Inquisidor da Espanha no período de Isabel I. Tornou-se famoso por suas campanhas contra a população judia e muçulmana, e contra todos aqueles a que o Tribunal da Inquisição acusava de heresia contra o catolicismo. Seu nome é utilizado para aludir a pessoas fanáticas e autoritárias. [Nota dos tradutores]

11 EOF, Octubre 1912, n. p. 3.

12 EOF, Septiembre 1913, p. 3.
} 
Como se observa, se a competência técnica e a origem nacional das gerências os punham a salvo de certas críticas, tanto que os trabalhadores pareciam compartilhar em parte os estereótipos da superioridade cultural européia sobre a qual se procurou legitimar a expansão imperialista de fins do século XIX, estas crenças não eram imutáveis. Além disso, aqueles estereótipos não impediam que as chefias estivessem expostas a uma pertinaz condenação, por seus vícios e licenciosidades pessoais. Com efeito, se as gerências ferroviárias não costumavam ser criticadas por sua falta de profissionalismo, o eram por sua decadência moral, em particular pelo costume de utilizar bens e recursos das empresas em benefício próprio e por seus hábitos licenciosos. Não eram poucas as denúncias contra as mais altas hierarquias que se concentravam em fatos de corrupção e na solicitação de dinheiro ou bens aos trabalhadores a fim de designar um emprego, uma promoção ou uma transferência para uma zona favorável. Assim, o correspondente dos oficiais, Tolosa, argumentava que, para pôr fim aos costumeiros abusos dos capatazes, era necessário que

o chefe deixe de fazer negócios e se ocupe do serviço dos empregados. Quem é ele para mandar os peões da empresa limpar galinheiros? Quem o autorizou a tirar peões da limpeza das plataformas para mandá-los a lavrar o campo de sua propriedade? Enfim, quem é ele para se opor às promoções quando não se levam galinhas ou lhe dão 50 pesos? Que? Pensa que não conhecemos seus procedimentos? Está equivocadíssimo. ${ }^{13}$

Outra razão que aparecia associada à ira e ao caráter abusivo de indivíduos teoricamente educados, provenientes de nações supostamente modernas, era o excesso de álcool. Tratava-se de um hábito que, segundo as cartas enviadas ao periódico sindical, se encontrava muito generalizado entre a chefia, tal como o ilustram as anedotas referentes ao tesoureiro da Ferrocarril Rosario a Puerto Belgrano. Um denunciante, denominado "um acirrado aliado", relatou que, em 13 de julho de 1913, o senhor tesoureiro, de origem francesa, partiu de Rosário,

\footnotetext{
com seu carro e suas indispensáveis bebidas de todas as classes, pois a qualquer hora que este mentecapto sai para pagar seus empregados com seus correspondentes haveres, não se vê outra coisa no carro que a ele se destina que um grande número de cálices e bebidas, como igualmente seu rosto bastante corado em razão do "trago", que todos sabemos é o seu sonho dourado.
} 
O estado de embriaguez fazia com que o tesoureiro demorasse a pagar as numerosas estações de sua incumbência e se comportasse grosseiramente, pagando aos empregados "sempre com impropérios". A indiferença de seus superiores, a bebida e uma arrogância que se atribuía a sua nacionalidade explicavam sua conduta. O autor da carta se perguntava, retoricamente, "crê o muito francês que faz um favor?" Era responsabilidade do diretor disciplinar o tesoureiro, de maneira a impedir que "suba à cabeça o cargo que ocupa na companhia das taças" e que "não trate tão grosseiramente os empregados." ${ }^{14}$

O gosto de gerentes e administradores pelo álcool era tratado com ironia em apelidos tais como "técnicos do whisky", significando que a especialidade dos chefes se aplicava tanto ao seu conhecimento da bebida como ao bom desempenho do serviço. ${ }^{15}$ Os abusos de um inspetor de tráfego da Ferrocarril Oeste, Sr. Lowentuel, eram atribuídos ao fato de que, "com suas bebedeiras, quer fazer cumprir estritamente o regulamento interno" e esperava-se que algum subalterno lhe desse as mínimas noções de educação "já que, segundo parece, não lhe foram dadas na Inglaterra!"16 Os maus-tratos e as grosserias de um inspetor de tráfego, Marty, eram atribuídos ao fato de que era "muito afeito ao whisky" e que se não fosse assim, seria necessário que para o "bem dos operários e da empresa" submetessem-no a um "estudo de psiquiatria."17 $\mathrm{O}$ alcoolismo explicava em muitas ocasiões as condutas despóticas e arbitrárias de seus superiores. De Alberdi se certificava de que um grupo de trabalhadores estava realizando sua tarefa, quando o Superintendente Sr. Chapper interrompeu-os para questionar a qualidade do trabalho e começou a "maltratá-los". Segundo consta, "este miserável estava por algum motivo 'atacado' o que não é estranho porque é afeito ao whisky", motivo pelo qual a maioria dos trabalhadores ignorou suas "brincadeiras de mau gosto". A carta, assinada por "um que pensa", concluía: "com certeza, estes toma-whisky estariam melhor em outro lugar do que nos postos de chefes; por exemplo: nas trincheiras, já que sua perda pouco poderia nos afetar." ${ }^{18}$ Ademais, a bebida aparecia associada ao jogo. Isto também figurava entre as

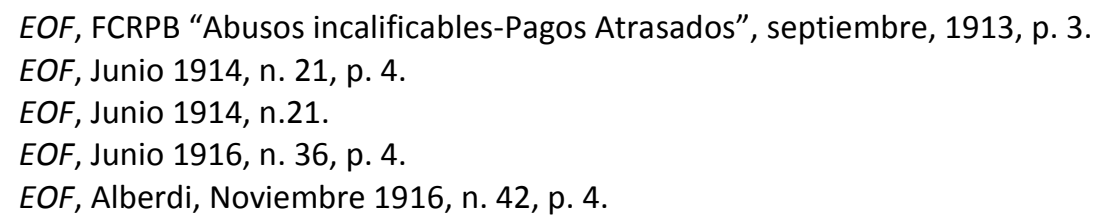


debilidades dos chefes, como ilustram os costumes do chefe de movimentação da Seção Onze, Ratti, o qual se destacava "especialmente por seu pretenso aspecto de Kaiser junto ao vício de jogar nas corridas." ${ }^{19}$ Outro chefe de estação da Central Argentina, denunciado por destituir arbitrariamente um trabalhador que pedia um descanso, era descrito como um "jogador e alcoólatra empedernido." De fato, este chefe havia descoberto o empregado destituído recostado na estação após as doze da noite, ocasião em que ele mesmo retornava à estação depois de ter "estado jogando no café do Sr. Gobbi". ${ }^{20}$

Os chefes e administradores eram os principais, mas não os únicos, responsáveis pelas arbitrariedades e injustiças que se sofria diariamente nas empresas. Os supervisores de menor nível e os capatazes também compartilhavam daqueles hábitos e condutas que caracterizavam as chefias. Contudo, neste caso, a distância social e cultural entre os trabalhadores e seus capatazes era muito menos acentuada. Deste modo, as críticas tendiam a centrar-se em questões tais como os mecanismos de promoção: afirmava-se, por exemplo, que a ascensão de capatazes e supervisores devia-se mais à sua condescendência para com a chefia do que às suas aptidões. Além das questões de mérito, reprovava-se que a ascensão profissional os levasse a esquecer ou denegar suas origens sociais, a trair seus valores e abandonar toda solidariedade para com seus iguais. Assim, "um lutador sindicalizado" de Santa Fé censurava a atitude de um encarregado da oficina de telégrafos que era "um dos nossos companheiros antigos", "um daqueles que ontem era empregado subalterno" e que a partir de sua ascensão a um novo cargo se achava "superior". ${ }^{21} \mathrm{~A}$ denúncia contra o "capataz Justino Montoya (krumiro)" refletia uma situação parecida. Sustentava-se que este levava "sua ruindade até a inacreditável pretensão de que os operários o tratem como senhor e lhe presenteiem com erva-mate e açúcar". Justino era incapaz de compreender o "alto conceito de dignidade" dos trabalhadores, pois presumia que todos seriam como ele, que "seguramente se arrastara como um réptil ante os superiores." ${ }^{22}$ Esta caracterização não era de nenhum modo excepcional. Ao

\footnotetext{
EOF, Febrero 1916, n. 35, p. 2.

EOF, San Marcos, Octubre 1915, p. 4.

EOF, Santa Fe, junio de 1914, n. 21.

EOF, Pergamino, septiembre 1914, n. 24, p. 4. [Grifo meu]
} 
relatar a trajetória laboral de capatazes e superiores, os trabalhadores costumavam ressaltar sua falta de adesão às greves ou sua indiferença à organização sindical. Nas cartas e informes das seções, os capatazes apareciam usualmente associados a termos como fura-greves ou "krumiro".

No entanto, cabe ressaltar que a Federação não impugnava a ascensão ocupacional em si mesma, e sim os meios condenáveis que alguns utilizavam para alcançá-la. Era a mobilidade social ascendente por meios pouco dignos, relacionados a favores e retribuições aos chefes, com deslealdade para com os companheiros oferecendo informações sobre a organização e delatando os militantes - o que se censurava. Da mesma maneira, condenava-se o afã individualista que levava alguns trabalhadores a aderir aos sistemas de pagamento e bonificações baseados na produtividade. A propaganda contra o sistema de trabalho por tarefa destacava que este contribuía para o "desenvolvimento do espírito egoísta", fomentava a competição e as brigas entre o pessoal. ${ }^{23}$ Inclusive, o periódico sindical não tinha dúvidas em transmitir as queixas daqueles trabalhadores cujos esforços lhes tornavam credores de ascensões e promoções, que injustificadamente Ihes eram negadas. Assim testemunha a história de um capataz de vias e obras de General Güemes, Salta, o qual depois de quase dez anos de trabalho foi despedido sob pretexto de racionalização. O demitido recorreu da decisão de seus chefes imediatos junto às autoridades superiores da Administração Geral das Ferrovias do Estado, o que provocou a indignação daqueles que, ao tomarem conhecimento, decidiram vingar-se, não o reintegrando ao trabalho. A breve descrição dos antecedentes laborais do demitido sublinha que sua ascensão havia sido merecida, baseada no seu esforço, dedicação e capacidades:

O operário José Hilario Ruiz, desde 1905, começou a trabalhar na repartição de Via e Obras, na humilde condição de peão. Devido ao seu bom comportamento e atitudes foi promovido a capataz. ${ }^{24}$

Seguramente, a aspiração de Ruiz assemelhava-se à de muitos homens que acreditavam poder construir uma carreira laboral em uma grande empresa, como eram as ferrovias, e alcançar gradualmente melhores postos do que tinham ao ingressar. Esta ética do trabalho era valorizada tanto quanto condutas honradas e 
meritórias, como as de Ruiz, e podia, sem dúvida, conciliar-se com a solidariedade de classe. A FOF tomava a defesa desse capataz como uma causa própria, digna de consideração, pois constituía uma dentre as tantas provas de injustiça e arbitrariedade das quais podiam ser vítimas um bom homem trabalhador. Da mesma maneira, ao sustentar um critério por mérito na seleção e promoção do pessoal, a Federação se opunha ao favoritismo étnico, que parecia predominar nas eleições dos supervisores em matéria de recrutamento e promoção laboral. Deste modo, tocava em um aspecto sensível no funcionamento de uma sociedade de imigração, na qual os mecanismos de indicação e as cadeias migratórias jogavam um papel central no mercado de trabalho. $^{25}$

A denúncia de um trabalhador da seção de Via e Obras da Ferrocarril Oeste revelava os rancores que suscitavam estes vínculos entre aqueles que ficavam excluídos das redes étnicas. $O$ denunciante tinha sido obrigado a renunciar porque 0 encarregado, Sr. Juan Cochi, quis substituí-lo por um de seus familiares, o "menino" Pedro Ogni, "violando, pisoteando todos os direitos do qual subscreve." Segundo informava Cochi, "dado os vínculos de compatrioterismo (sic), o ampara e o protege como se fossem filhos de uma mesma mãe." Para explicar a impossibilidade de sobrepor-se a esta rede, oferecia uma descrição contundente das condutas e hábitos do encarregado e seu protegido. Eles eram

assíduos freqüentadores dos lugares "infectados de peçonha e ao "hotel do galo $^{\prime \prime *^{*}}$; dotados de faculdades para falar corretamente a verdadeira linguagem "lunfardo" ${ }^{\prime * *}$ sempre encontram os canalhas, o amparo e proteção de outros da mesma "cria". E essa coalizão de elementos, se realizou, e fez com que fosse obrigado a renunciar... ${ }^{26}$

25 A respeito da relevância das redes migratórias e do associacionismo étnico para a integração dos imigrantes europeus na Argentina, ver DEVOTO, Fernando. Historia de la inmigración en la Argentina. Buenos Aires: Sudamericana, 2003.

* "Hotel del Gallo" é uma expressão de lunfardo que se refere ao departamento de polícia de Buenos Aires. Ver Diego GALEANO, Diego, Escritores, detectives y archivistas. La cultura policial en Buenos Aires. 1821-1910, Buenos Aires: Teseo - Ediciones Biblioteca Nacional, 2009, p. 49. [Nota dos tradutores].

* Lunfardo é um vocabulário composto de gírias empregado em Buenos Aires desde fins do século XIX, associado ao tango e ao baixo mundo. Ver a definição da Academia Porteña del Lunfardo, http://ar.geocities.com/lunfa2000/queesellunfardo.html (página consultada 30.07.2009, 09:24). [Nota dos tradutores]

${ }^{26}$ EOF, Justa Protesta, Octubre 1915, n. 33, p. 4. 
É necessário notar que, ainda que a acusação descreva os efeitos negativos que o funcionamento das redes migratórias acarretava sobre aqueles que não pertenciam a elas, a condenação ao favoritismo do encarregado e seu procedimento centrava-se muito mais em uma impugnação ética. O que se censurava era, definitivamente, os hábitos destes sujeitos contrários à decência e honorabilidade masculinas que deviam caracterizar todo bom trabalhador. Com esta ênfase na dimensão moral, se apelava de maneira ampla a todos os ferroviários, os quais, para além de suas origens, categorias profissionais ou idade, deviam - supostamente - compartilhar valores e princípios que faziam a "hombría de bien" ${ }^{*}$. Como ilustram muitos dos testemunhos aqui analisados, um ferroviário ansiava vestir-se com compostura, falar com correção, capacitar-se e ascender a fim de alcançar uma posição que lhe permitisse ser responsável frente a sua família e ser socialmente valorizado e respeitado como um homem digno. Precisamente, as chefias, os supervisores e capatazes pareciam desconhecer estes códigos e valores, exibindo comportamentos moralmente desonrosos e condenáveis. A tal ponto tal que, uma carta assinada simplesmente por "um operário" os qualificava como "tipos que parecem ter vindo ao mundo com a única missão de testemunhar a teoria do delinqüente nato posta em voga pelo finado Cesar Lombroso." Sustentava que,

nas ferrovias (falamos do exército de mandões) os delinqüentes, criminosos,

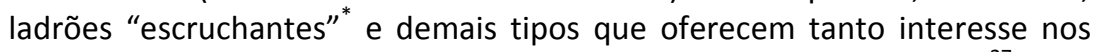
tratados de antropologia criminal, abundam mais do que nas cadeias. ${ }^{27}$

Se estas advertências sobre a arbitrariedade das gerências e supervisores, ou os vívidos relatos sobre os abusos cotidianos, não resultavam suficientes, a narrativa detalhada de histórias com final trágico constituía um último recurso para dar conta das tensões e violências que a discriminação cotidiana trazia para o mundo do trabalho. Certamente, entre as cartas e informes das seccionais enviadas ao jornal EOF, distinguem-se duas notícias fatais protagonizadas pelos trabalhadores representados pela Federação, intituladas "morte de um déspota" e "dolorosa tragédia". A primeira relatava os episódios ocorridos no dia 23 de agosto de 1913 nas

\footnotetext{
* "Hombría de bien”: refere-se a um homem digno, honesto, decente. [Nota dos tradutores]

Escruchante, em lunfardo, significa um ladrão que age de maneira violenta, um criminoso. [Nota dos tradutores]

${ }_{27}$ EOF, "Villa Mercedes. Superiores modelos" septiembre 1913, n. 13, p.
} 
oficinas da Ferrocarril Oeste em Liniers, onde um trabalhador, Avelino Zapico, havia matado o chefe da seção de acoplagem de vagões, Parides Nicoleti, ao disparar-lhe dois tiros. O fato relatado na segunda notícia deu-se em junho de 1914, nas oficinas Alianza da Ferrocarril Pacífico em Santos Lugares, onde um jovem operário, Benigno Paredes, matou um capataz depois de uma violenta disputa com um chefe e depois se suicidou. ${ }^{28}$ Estes casos não surpreendem, à luz dos inúmeros episódios de violência física e verbal denunciados no jornal da Federação. Apesar disso, merecem ser analisados em detalhe, pois exemplificam que os trabalhadores viam ameaçada a sua identidade masculina tanto por causa das dificuldades que enfrentavam para converter-se em provedores do bem-estar da família como devido às ofensas diárias à sua reputação.

Foram as cartas e informes dos trabalhadores e representantes sindicais que divulgaram alguns dados da vida destes jovens. Apesar de tratar-se de informação fragmentada, as trajetórias de Avelino e Benigno permitem vislumbrar a vulnerabilidade experimentada por alguns homens migrantes e os múltiplos fatores que complicavam sua já frágil situação. Contassem ou não com sólidas redes migratórias que os assistissem em sua chegada e instalação na Argentina, a migração expunha estes jovens a desafios, incertezas e, eventualmente, a profundas desilusões. Não há dúvidas de que para nenhum dos dois jovens foi simples encontrar um trabalho satisfatório, uma dificuldade que seguramente se agravou devido à recessão econômica e pelo fato de que não contavam com uma especialização ou ofício. Sob estas circunstâncias, ambos se encontraram mais expostos à concorrência no mercado de trabalho e, conseqüentemente, à obtenção de baixas diárias que lhes impediam de manter uma mínima capacidade de economia. Inclusive, na origem desses apertos, planejaram voltar à Espanha pouco antes de desencadearem-se estes episódios trágicos. Segundo se apurou, Avelino Zapico "custou muito achar ocupação" e estava a ponto de retornar quando conseguiu um posto de peão em uma oficina. Insatisfeito com o magro salário que ali the pagavam, procurou um novo emprego e, graças à ajuda de um amigo, ingressou finalmente nas Oficinas Liniers. Por sua parte, Benigno Paredes, depois de dois anos passados na Oficina Alianza, havia solicitado uma

${ }^{28}$ EOF, “F.C.O. Liniers, Muerte de un déspota”, Septiembre 1913, n. 14 y "FCP. Alianza, Dolorosa Tragedia", Julio 1914, n. 22, p.3. 
promoção com a esperança de melhorar sua remuneração a fim de economizar dinheiro para regressar. No entanto, sua petição não só lhe foi negada, como lhe foi designado, como represália, um trabalho mais "penoso e pior remunerado".

Ainda neste contexto adverso, ambos jovens persistiram em seu trabalho esforçado e em uma conduta digna, atitudes que destacavam todas as cartas de apoio enviadas ao Obrero Ferroviario a propósito destas tragédias. Sobre Avelino Zapico, destacava-se que cumpria com perfeição o ideal do militante comprometido. Uma missiva publicada dois anos mais tarde de ocorrida a tragédia recordava-o como "abnegado soldado da causa emancipatória", detalhando que desde os 16 anos havia pertencido ao Sindicato dos Mineiros de Asturias e contribuído com a criação de algumas seccionais na região. Explicou-se que ali trabalhara até que "em busca de horizontes mais amplos decidiu mudar-se para a Argentina". Ingressou nas Oficinas Liniers como peão encarregado do transporte de carvão para as locomotivas e depois foi transferido para a seção de acoplagem de vagões. Neste último posto, segundo informa uma carta, "tocou-Ihe sofrer muito pela circunstância de que só obtinham bons contratos aqueles que adulavam aos chefes e lhes repartiam suborno". Apesar de necessitar muito de um bom salário, Avelino não estava disposto a transigir e adequarse a práticas que julgava condenáveis. Como se destacou, preferia manter sua "retidão e honestidade" à custa de ser discriminado. Por sua vez, a conduta de Benigno Paredes ilustrava o modelo de bom filho e futuro marido exemplar. Ele era descrito como um jovem trabalhador "cuja única preocupação era a de reunir um miserável dinheiro que Ihe permitisse regressar à Espanha, onde era esperado por sua mãe idosa e a noiva, única e suprema ilusão de sua existência". ${ }^{29}$ Segundo informaram seus companheiros, sua integridade e hombridade ficavam demonstradas pelo fato de que, apesar de sua mãe oferecer-lhe remessa de dinheiro, "não queria sofrer esta humilhação de chegar ao lado de sua noiva com dinheiro que não foi ganho com o suor de sua testa, e recusou a oferta generosa de sua idosa mãe". Em suma, o jornal da Federação não deixava dúvidas de que se tratava de jovens honrados que, apesar das circunstâncias desfavoráveis, mantinham-se comprometidos com sua família e sua classe, como cabia esperar de todo bom trabalhador.

\footnotetext{
${ }^{29}$ FCP. Alianza, Dolorosa Tragedia", Julio 1914, n. 22, p.3.
} 
Para a Federação, eram as chefias que deviam ser responsabilizadas por estes episódios funestos. As desventuras destes jovens conduziam, assim, a um tema recorrente: a arbitrariedade e o autoritarismo do pessoal superior e dos capatazes. 0 supervisor assassinado em Liniers, Sr. Nicoletti, foi qualificado como a "nata do despotismo". Ainda que sobre o capataz Sánchez assassinado pelo jovem Paredes, em Santos Lugares, não se dessem maiores precisões, assim se descreveu a atitude do chefe causador da tragédia. Benigno Paredes havia sido designado à seção de pinturas de vagões, onde teve uma discussão com outro operário que terminou em uma briga. Apesar de acabar ferido, Benigno passou um breve tempo na prisão e, depois de pagar uma fiança, foi liberado. Ao retornar ao trabalho foi informado que havia sido substituído, motivo pelo qual solicitou uma reunião com o chefe e lhe pediu para ser reincorporado. Segundo informou-se, o chefe "fleumático e irônico" negou-lhe, respondendo somente: "você é um louco". Diante desta resposta, Paredes sacou um revólver e disparou. Como o chefe se fingiu de morto, foi acudido por alguns operários e capatazes, entre eles Sánchez, que tentou sacar um revólver. Ao perceber, Paredes disparou e o matou. ${ }^{30}$ Como se pode observar, para os informes do jornal sindical, não era casual que os chefes se convertessem nos principais alvos das represálias destes jovens, depois de ter suportado as injustiças e abusos daqueles. Da perspectiva da Federação, visto que as chefias discriminavam de maneira consciente e com deslealdade, a resposta violenta destes trabalhadores se encontrava legitimada.

$\mathrm{Na}$ verdade, é provável que os trabalhadores não demandassem muitos esclarecimentos para compreender a ação vingativa de Avelino e Benigno, não só pelo fato óbvio de serem testemunhas diretas destas tensões no mundo do trabalho, mas porque seguramente compartilhavam dos mesmos códigos culturais destes trabalhadores. Como Sandra Gayol bem demonstrou em seu estudo, responder com violência a ofensas graves para reparar a honra pessoal constituía um hábito amplamente praticado pelos setores populares - nativos e estrangeiros - ao final do século XIX na cidade de Buenos Aires. Segundo esta historiadora, a defesa da honra se conseguia, em última instância, através da violência física pessoal, em geral mediante

\footnotetext{
${ }^{30}$ EOF, FCP, Alianza “Dolorosa Tragedia”, julio 1914, p. 3.
} 
o uso de armas. ${ }^{31}$ Neste universo cultural, era compreensível que Avelino e Benigno optassem por reparar sua hombridade agravada através destes atos de coragem. 0 fato de que fossem trabalhadores homens não era absolutamente um dado menor. Os excessos da ação individual eram aceitos e justificados precisamente por isso, não sendo assim quando as envolvidas eram mulheres, como bem demonstrou a sugestiva análise de Dora Barrancos sobre a punhalada de uma mulher telefonista em seu chefe depois de ser despedida. ${ }^{32}$

Mesmo que o espaço de trabalho não permanecesse impermeável às formas de sociabilidade e aos valores culturais que regiam a vida cotidiana dos indivíduos em outros âmbitos, é evidente que nele a dinâmica das relações pessoais adquiria características específicas. Como destaca S. Gayol, os enfrentamentos por questões de honra supunham cenários e contextos livres de qualquer desigualdade entre os rivais, onde estes ficariam efetivamente equiparados. Se os cafés ou as ruas proporcionavam o âmbito adequado para estes enfrentamentos orientados a medir e, em boa medida, igualar-se na defesa da honra, o mundo do trabalho não oferecia de nenhum modo o cenário propício. No espaço de trabalho, as relações de poder colocam os sujeitos em posições de clara desigualdade. É verdade que o ritual da violência desencadeada nas oficinas ferroviárias se ajustou a algumas das regras estabelecidas nos duelos populares: existia uma história de animosidade entre os rivais, os agravos já não podiam corrigir-se por meio de palavras e a resolução era fundamental para a vitória na briga. Contudo, a grande diferença consistia em que os riscos não estavam divididos igualmente, pois não se partia de condições materiais de igualdade. Conseqüentemente, ainda quando as condutas de Avelino e Benigno tenham se imprimido nesta lógica cultural e sido compreendidas a partir destes valores, suas histórias abriam uma interrogação e um desafio para os sindicatos ferroviários: que sentido tinha que estes jovens reparassem sua honra desta maneira, se isto os conduzia à sua destruição pessoal, apesar, inclusive, da vitória na briga? Vale lembrar que depois destes episódios, Benigno se suicidou e Avelino foi condenado a mais de 17

31 GAYOL, Sandra. Sociabilidad en Buenos Aires. Hombres, Honor y Cafés, 1862-1910. Buenos Aires: Ediciones del Signo, 2000, p. 185-240.

32 BARRANCOS, Dora. "La puñalada de Amelia (o cómo se extinguió la discriminación de las mujeres casadas del servicio telefónico en la Argentina)". Revista Trabajos y Comunicaciones, Segunda Época, no 34, Departamento de Historia, Universidad Nacional de La Plata. 
anos de prisão em Ushuaia. Mais ainda, as cartas e informes destacavam que este tipo de respostas individuais não conseguia melhorar a situação do conjunto dos trabalhadores: o despotismo dos chefes continuava sendo moeda corrente, a "imprensa burguesa" qualificava estes atos de "selvagens assassinatos" e, por sua vez, a "justiça burguesa" se mostrava inabalável.

É possível pensar que as histórias de Avelino e Benigno convidariam a refletir sobre a necessidade de flexibilizar o ideal de trabalhador intransigente com as chefias, leal à sua classe e à sua família, sobretudo em contextos adversos. Em boa medida, ao obstinar-se com o cumprimento incondicional destas prescrições e modelos normativos em uma conjuntura pouco apropriada para sua realização, este ideal teria contribuído para conduzir estes jovens a um beco sem saída. No entanto, a moral que surgia das reflexões do jornal sindical não se orientava nesta direção, mas na contrária. As vidas de Avelino e Benigno ofereciam, neste sentido, uma trajetória exemplar, modelos de hombridade a serem seguidos e imitados. $\mathrm{O}$ ideal de bom trabalhador com procedimento digno, capaz de ganhar o respeito em seu trabalho e em sua família, era inegociável. Só que para defender essa "hombría de bien" devia apelar para a solidariedade do conjunto, à irmandade e à organização coletiva, e não à reparação individual da honra pessoal.

\section{O MODELO DE FERROVIÁRIO CONSCIENTE E MILITANTE}

Se a defesa da reputação dependia da organização e não da ação individual, o fortalecimento da corporação convertia-se em uma prioridade urgente. Claro que para isso era necessário estimular uma transformação individual dos homens trabalhadores, fomentando sua ação generosa e desinteressada em nome da solidariedade com seus companheiros de trabalho e em prol do ideal emancipador. Não é casual que a imprensa sindical privilegiasse a difusão das histórias de vida dos militantes como um modelo a ser seguido. Por exemplo, em 4 de abril de 1914 realizou-se, segundo recordava um testemunho enviado a EOF, um assado campestre para a despedida de Ángel Saisi, um jovem de 19 anos que, cansado das "injustiças cometidas pela empresa 
contra sua pessoa", decidia deixar o trabalho. No entanto, Ángel assegurava que não ia fechar os ouvidos a seus companheiros, "aos explorados como eu". Sua trajetória era enaltecida devido a sua dedicação à atividade sindical, graças à qual se havia organizado uma seção em Mar del Plata e outra seccional na Ferrocarril Sud. A carta assinada por "um ferroviário" urgia a tomar "o exemplo deste modelo de homem e seguir o mesmo caminho". ${ }^{33}$ O modelo a imitar era claro: o militante comprometido. Que um jovem dedicasse seu tempo livre ao trabalho solidário a favor dos interesses proletários e continuasse se preocupando com o destino da corporação, mesmo depois de se retirar, constituía um exemplo louvável, um ideal a ser imitado; particularmente, por se tratar de um indivíduo provavelmente solteiro, cujo tempo livre poderia ser dedicado ao ócio, entretenimentos ou outras múltiplas atividades. Ocupar-se da organização sindical, de tarefas em prol do bem coletivo, relegando os prazeres pessoais, constituía uma mensagem reiterada uma ou outra vez aos jovens trabalhadores. Uma carta de um federado assim ilustra ao aconselhar seus companheiros dizendo: "afaste-se das tabernas e dos prostíbulos e da libertinagem que corrompe e denigre e recuse todo 'conchavo ${ }^{*}$ com os patrões.'". ${ }^{34}$

Enquanto que para conseguir o empenho dos homens solteiros, o sindicato devia distanciá-los daqueles espaços de sociabilidade que considerava perniciosos, também devia convencer os homens casados de que o compromisso fraterno entre trabalhadores não atentava contra sua paternidade responsável. Sustentar uma família não devia constituir um obstáculo para aproximar-se da organização sindical, trabalhar e comprometer-se com ela. Pelo contrário, parte da responsabilidade de um bom pai de família devia ser, segundo explicitavam alguns informes e cartas, assegurar um futuro mais justo para seus descendentes. Assim, uma das cartas argumentava:

\footnotetext{
Não esqueça que devemos aniquilar nossos poderosos inimigos, os capitalistas [...] Se não conseguimos obter esta satisfação, nossos filhos nos criticarão por ter-Ihes deixado uma vida de escravos. Companheiros indiferentes: não querem deixar a vossos filhos o direito de que amanhã possam gritar a pulmão cheio? Estas glórias devemos a nossos pais e a todos os nossos antepassados...! $!^{35}$
}

33 EOF, FCS, Chelforo, mayo 1914, n. 20, p. 4.

No original: 'contubernio con los amos', que carrega um tom pejorativo; contubérnio remete a uma relação de concubinato. [Nota dos tradutores]

34 EOF, Junio 1914, n. 21, p. 4

35 EOF, Cañada de Gómez, Octubre Noviembre de 1914, n. 24-5, p. 3. 
Dedicar tempo à organização era um lema dirigido tanto a jovens solteiros como a homens casados, a fim de assegurar uma defesa exitosa dos interesses dos ferroviários. Para isto, requeria-se, também, converter-se em um trabalhador preparado. Ao tempo dedicado à militância deviam se somar algumas horas destinadas à leitura, à educação e à convivência fraterna com os companheiros de trabalho. Por este motivo, as seccionais se ocupavam de organizar bibliotecas como o testemunha a seccional da cidade de Olavarría da Ferrocarril Sud. Ali, "imitando aos camaradas de outras seções", resolveu-se organizar uma "modesta biblioteca". A mesma serviria para que ali os trabalhadores se familiarizassem com todas as publicações operárias remetidas e oferecia um espaço "para mudar impressões e estreitar vínculos de amizade e de companheirismo". ${ }^{36}$ A organização das bibliotecas constituía uma atividade social em si mesma, à qual os trabalhadores e suas famílias dedicavam boa parte de seus esforços. Para criar uma delas em Tafí Viejo, Tucumán, realizou-se "um espetáculo cinematográfico" enquanto que, em Trenque Lauquen, fazia-se saber que para fundar a biblioteca se havia posto em circulação uma rifa. ${ }^{37}$

Como se pode observar, o compromisso militante exigia generosidade em termos de tempo e eventualmente de dinheiro. Com freqüência, circularam subscrições para assistir aos trabalhadores em momentos de dificuldade: demissões injustificadas, acidentes, ou inclusive a morte. Uma assembléia em Pergamino, por exemplo, decidiu doar 10 pesos ao guarda Ramón Villarino, depois de ter sido destituído da empresa como represália a sua militância sindical. A notícia destacava que se tratava de um "pai de uma numerosa família, que, por conseqüência da falta de trabalho, se encontra em uma crítica situação". ${ }^{38}$ Ainda que se reconhecesse que a doação fora modesta, Ihe havia bastado para o fundamental: transferir-se para outra localidade em busca de trabalho. No mesmo sentido, as doenças e acidentes fatais requeriam as contribuições de todos e estes casos mereciam uma detida cobertura no jornal. Era possível seguir a evolução do estado de saúde de seus companheiros e, inclusive, como no caso de Laureano Wilson, lamentar seu falecimento. O dinheiro

\footnotetext{
${ }^{36}$ EOF, FCS, Olavarría, Septiembre 1914, n. 24, p. 3.

${ }^{37}$ EOF, Tafí Viejo, Septiembre 1914, n. 24, p. 4 y EOF, Trenque Lauquen, Octubre-Noviembre 1914, n. 25 y 26, p.4.

${ }^{38}$ EOF, Pergamino, Septiembre de 1914, n. 24, p. 4.
} 
recolhido era entregue então à viúva. O jornal se congratulava de que estes gestos, ainda que parecessem mínimos e não pudessem evitar que se reiterassem estes infortúnios, reforçavam os "vínculos de companheiros e suavizavam a angústia". ${ }^{39}$

Os informes sobre os acidentes fatais ressaltavam o futuro incerto que esperavam os familiares cujo bem-estar emocional e econômico dependia do trabalhador. Assim ocorre com a morte de Victoriano Álvarez, um jovem de 28 anos, recordado por sua "seriedade", "bom trato" e compromisso com a Federação. Sobre a situação de sua família se afirmava: "a desconsolada esposa e cinco ternos filhinhos choram inconsoláveis ao bem amado protetor, possuídos pela cruel angústia que lhes proporciona o futuro de incógnita incerteza". Frente à atitude da empresa, que se negava a pagar a indenização por acidente, acusando a vítima de "imprudência", os companheiros de trabalho recolheram dinheiro para colaborar com as necessidades mais imediatas desta numerosa família. ${ }^{40}$ Por sua vez, estes gestos eram correspondidos, fortalecendo um sentido de comunidade para além dos trabalhadores homens. Em certas ocasiões, os familiares das vítimas tornavam público seu agradecimento, tal como expressava a viúva de um maquinista, que havia recebido uma doação de parte dos companheiros de seu defunto marido. Manuela T. de Barrios enviou uma carta solicitando que se publicasse seu agradecimento nas "colunas do Operário Ferroviário, porta-voz dos interesses da família ferroviária." ${ }^{41}$

Vale notar que o ideal do ferroviário consciente se tornava explícito tanto pelo que se dizia acerca do bom trabalhador e militante como pelo muito que se informava sobre seu oposto: o trabalhador "carneiro", alvo predileto de boa parte da correspondência enviada ao periódico. Em cada um dos números nunca faltou a descrição de algum membro da chamada "fauna carneiril" como se aludia aos trabalhadores vinculados aos sindicatos "amarelos", ou seja, alinhados com as empresas. A greve do início de 1912, organizada por La Fraternidad e as campanhas de organização da FOF agravaram as tensões entre os militantes sindicais e os grupos "amarelos", como a "Reforma Ferroviaria" e a "Asociación Ferrocarril Nacional". Ocasionalmente, estes conflitos encontravam eco no jornal da Federação. Em um

\footnotetext{
${ }^{39}$ EOF, Junio 1914, p. 4.

40 EOF, Ameghino, Febrero de 1916, n. 35, p. 2.

41 EOF, "Actos de solidaridad", Listas de suscripciones a favor de esposas, familiares y trabajadores accidentados, Diciembre, 1915, p. 3 y EOF, Febrero de 1916, n. 35, p.3
} 
informe firmado sob o pseudônimo "Loteria", um agremiado respondia às acusações realizadas pelo que denominava o pasquim Tribuna Ferroviaria, jornal de um dos sindicatos favoráveis à empresa. ${ }^{42}$ "Loteria" acreditava estar respondendo a uma afronta que não era em absoluto menor, pois os membros da FOF tinham sido qualificados como "covardes" e "rufiões", menosprezando claramente a honorabilidade masculina dos militantes. "Loteria" defendia seus companheiros sindicais, acusando os "carneiros" de verdadeiros covardes, argumentando que, na verdade, estes últimos é que demonstravam "sua incapacidade de fazer nada prático pelo mesmo temor que sentem de ver em perigo suas posições conquistadas à força de delação e servilismo". Também, explicava que "não teria vergonha em internar em um prostíbulo suas mulheres e filhas a fim de poder saciar seus enormes apetites". ${ }^{43}$ Da perspectiva dos membros da FOF, a valentia não consistia na ostentação da força e da virilidade, mas na posse de saberes úteis, graças aos quais um homem era capaz de proceder e conduzir-se. Isto pressupunha a capacidade de ganhar o sustento por si mesmo e não na base do trabalho de uma mulher, invertendo o princípio do ideal do homem responsável por prover o bem-estar material da sua família.

Como se pode ver, as práticas e valores atribuídos aos "carneiros" representavam os princípios opostos que deviam guiar a moral de um trabalhador consciente e um verdadeiro militante. $\mathrm{O}$ abismo que separava estes últimos daqueles se manifestava na descrição dos membros da "galeria carneiril" proposta por um colaborador da seção de General Pico. A mesma estava integrada por três indivíduos carentes das virtudes próprias de todos os homens de bem. Um deles, Manuel Martínez, era um foguista que não conseguiu ser aprovado no exame de maquinista em nove anos, razão pela qual era apelidado de "O Inservível". Outro, aliás, "O Tuberculoso", havia se tornado famoso por sua bisbilhotice e devido ao seu "deplorável estado de saúde" cumpria funções limitadas. Finalmente, Pablo Ferrando, chamado de Don Cornelio, "devido a certas manifestações hostis feitas por nossos companheiros" havia pedido transferência para assegurar o mínimo de tranqüilidade. A mensagem não deixava espaço para ambigüidades: um trabalhador capaz e digno,

42 EOF, Febrero de 1916, n. 35, p. 3

* No original, lunfardo: Cafinflero. [Nota dos tradutores]

43 EOF, Febrero de 1916, n. 35, p. 3 
da perspectiva sindical, se caracterizava pela posse de certas capacidades intelectuais e físicas que Ihe garantiam a ascensão no ofício, o desempenho de todas as tarefas sem limitações e o respeito dos membros do seu lar, em particular a lealdade de sua esposa.

A estas qualidades que compunham a figura do bom trabalhador se somava ainda o espírito de solidariedade. Não se tratava de um sentimento de irmandade entre os companheiros de trabalho que se reduzia a uma simples atitude declamatória. Este traço devia arraigar-se e expressar-se em práticas cotidianas que revelavam um compromisso sustentado com o bem-estar coletivo dos trabalhadores. Atendo-se a estes princípios, os ferroviários, conseqüentemente, não podiam permanecer alheios às infelicidades dos trabalhadores mais vulneráveis. Não é surpreendente que a Federação tivesse organizado coletas para financiar a defesa de Avelino Zapico e construir um mausoléu para Benigno Paredes, assim como para enviar algum dinheiro a sua família. ${ }^{44}$ Apesar de não estarem isentas de dificuldades, as campanhas foram levadas adiante com persistência. ${ }^{45}$ Como a defesa judicial de Avelino não teve êxito, ao assumir a presidência Hipólito Yrigoyen*, a Federação pediu a seus associados e aos da La Fraternidad que assinassem uma petição para ser apresentada ao novo presidente, solicitando sua absolvição. Se esta "agitação pró indulto de Avelino", como se denominou este esforço, dava conta exata das práticas nas quais se fundava o espírito de solidariedade entre os ferroviários, a carta da Federação ao presidente merece ser citada, pois sintetiza o modelo de masculinidade que, simbolizado na história de vida daquele jovem, promovia o sindicato. Certamente, era em nome de sua cabal e íntegra trajetória como filho e companheiro de trabalho que seus pares reclamam sua liberdade. Com a solenidade de rigor, explicaram ao presidente,

Respeitamos a coisa julgada que a sentença importa, ainda que os companheiros do processado naquela triste emergência seguem ainda acreditando ser ele alheio ao delito de que foi vítima o encarregado Nicoletti, chefe na ocasião da seção em que se montam os vagões. Por outro lado, a má vontade para com os operários que caracterizava o ex-

44 EOF, Febrero 1914, n. 17, p. 2 y EOF, Monte Caseros, septiembre 1914, n. 24, p. 4. EOF, octubrenoviembre y diciembre, 1916.

45 EOF, Diciembre de 1916 , La Fraternidad, Junio,191.

* Hipólito Irigoyen, pertencente a UCR (União Cívica Radical), foi o primeiro presidente argentino (1916-1922) eleito sob a lei sáenz peña, que garantia o voto universal, secreto e obrigatório [Nota das editoras]. 
encarregado mencionado; os abusos, as multas freqüentes e injustas que impunha e a destituição infundada e arbitrária de muitos trabalhadores com o único objetivo de obtenção de suborno dos requerentes puderam ser os fatores determinantes da ação atribuída a Zapico, que também havia sido afastado injustamente do trabalho. Foi este o causador da morte daquele? Assim o declarou a justiça; mas os bons antecedentes de Avelino Zapico, o conceito de bom companheiro que se Ihe atribuía, a ajuda a seus pais idosos, enviando a Espanha uma boa parte de seu escasso salário, nos permitem acreditar que em seu ser não existem instintos anti-sociais, e nos levam a pensar que o ato pelo qual a justiça o condenou é o fruto de um momento de irreflexão e como conseqüência dos maus tratos do encarregado.

E convictos de que Avelino Zapico não é um delinqüente, e sim um operário modesto e trabalhador, os que assinam abaixo confiam na ampla visão do primeiro juiz da nação e em que seu conceito, pelo mesmo mandato da constituição, não está sujeito por nenhuma outra consideração que a do bem geral, que neste caso não surge com o indulto ou comutação da pena que solicitamos, mas que coincide com a felicidade de seus pais idosos, que tudo esperaram da magnanimidade de V.S.; a esta recorrem também esperançosos de que o Excelentíssimo Senhor presidente da nação irá sobrepor a justiça verdadeira aos rigorosos ditames dos encarregados de aplicar as leis respectivas.

Digne-se o Sr. Presidente atender esta súplica. ${ }^{46}$

Depois de quase quatro anos de campanha, em junho de 1917, La Fraternidad felicitou a Federación Obrera Ferrocarrilera pelo êxito obtido e celebrou ver Avelino Zapico "respirar com pulmão cheio o ar da liberdade que tão desmerecidamente the arrebataram". Era evidente que as mudanças políticas inauguradas pela lei eleitoral de 1912 abriam novas oportunidades aos trabalhadores. Nestas circunstâncias, a União Cívica Radical, o partido que havia alcançado o governo nacional com a vitória eleitoral de 1916, não podia ignorar as demandas dos trabalhadores. Assim, poucos meses depois do indulto a Zapico, mais precisamente em 24 de setembro de 1917, La Fraternidad e a Federación Obrera Ferrocarrilera se uniam para declarar a primeira greve geral ferroviária na história do país.

\section{CONCLUSÕES}

Há vários anos, sintetizando os avanços e as tarefas pendentes na historiografia sobre gênero e trabalhadores na América Latina, John French e Daniel James

$46 \quad$ La Fraternidad, Junio 1, 1917. 
chamaram a atenção para a necessidade de reconstruir os diferentes modelos de masculinidade preponderantes entre os setores populares e suas mudanças através do tempo. Estes autores sugeriram que era necessário contextualizar historicamente as masculinidades da classe trabalhadora e advertiram sobre a importância de dar conta da sua heterogeneidade, destacando que, à medida que se iniciava a revisão dos estereótipos associados ao machismo, deveria se explorar a relevância de outros ideais e outras prescrições, como, por exemplo, o da paternidade responsável, uma questão ainda pouco indagada na literatura sobre a região. ${ }^{47}$ Este artigo tentou avançar nesta direção ao tomar como caso de estudo os trabalhadores ferroviários na Argentina do início do século XX. Ao utilizar o conceito de gênero como categoria de análise para examinar a correspondência e os informes publicados no periódico da Federación Obrera Ferrocarrilera, acreditamos que foi possível enriquecer nossa compreensão da cultura do trabalho dos ferroviários e dos valores defendidos por suas organizações operárias. Em particular, pôde-se advertir que as expectativas que o emprego em uma ferrovia gerava entre os trabalhadores eram indissociáveis de suas noções de respeitabilidade e honorabilidade masculinas, de suas concepções dos direitos e obrigações de um homem digno. Levar em conta as idéias sobre a diferença sexual que moldavam as aspirações e protestos dos trabalhadores nos permitiu revelar a centralidade que a ideologia do homem como responsável pela manutenção familiar adquiriu entre os trabalhadores ferroviários nas primeiras décadas do século XX.

Naturalmente, se estas expectativas arraigadas e compartilhadas por muitos dos homens que ingressavam e aspiravam manter um emprego nas ferrovias tornavam-se difíceis de serem concretizadas em tempos de prosperidade, o foram ainda mais em períodos de crise. Como se tentou demonstrar aqui, as economias e planos de racionalização implementados pelas empresas ferroviárias durante a Primeira Guerra Mundial na Argentina resultaram em demissões, cortes salariais e restringiram as possibilidades de ascensão. Neste contexto adverso, os temores e inseguranças dos trabalhadores para assegurar o sustento de suas famílias se intensificaram, enquanto o futuro de jovens e migrantes recém-chegados foi seriamente comprometido. As cartas e informes do jornal sindical privilegiaram e

47 FRENCH, John e JAMES, Daniel (eds.) The Gendered Worlds of Latin American Women Workers. Durham: Duke University Press, 1997, p. 1-30. 
tornaram públicas estas angústias comuns a um vigoroso grupo de ferroviários, para além de suas diferenças de qualificação ou ofício, nos anos prévios ao estouro da grande greve ferroviária de 1917. Claro que, conforme se explicou, se a conjuntura econômica recessiva exacerbava a preocupação dos trabalhadores com relação às suas possibilidades de sustentar seus lares, existia um elemento estrutural ao mundo do trabalho ferroviário de princípios do século que contribuía para esta insegurança: a falta de coerência e transparência nas regras de recrutamento e promoção trabalhista, assim como a arbitrariedade e autoritarismo no tratamento pessoal. Os favoritismos no recrutamento e ascensão do pessoal sobre a base de relações étnicas constituíam um traço característico do mercado de trabalho em uma sociedade de imigração massiva, como era a Argentina do final do século XIX e início do século XX. A troca de favores e as relações clientelistas também pareciam fazer parte dos mecanismos necessários para a obtenção de um trabalho, uma melhoria ou promoção. A violência verbal e física se somava a este quadro de arbitrariedade no cotidiano do trabalho, que enchia de denúncias as cartas enviadas ao jornal da Federação.

Cabe reconhecer que esta arbitrariedade no mundo do trabalho não constituía um traço exclusivo das empresas ferroviárias na Argentina. Também ao final do século XIX, nos Estados Unidos, o trabalho ferroviário carecia de regras claras em matéria de sanções disciplinares, contratações, remuneração e transferências, promoções, indenizações e benefícios extra-salariais. Por esse motivo, em nome da segurança, justiça e estabilidade, os trabalhadores se organizaram para solicitar procedimentos transparentes e estáveis com a finalidade de conseguir um melhor controle da sua experiência de trabalho, que lhes assegurassem maior segurança e autonomia. ${ }^{48}$ Apesar disso, o que se pretende ressaltar aqui é que este persistente caráter discricionário e arbitrário constituiu, em última instância, uma ameaça para a identidade masculina dos trabalhadores. De tal modo que, para compreender cabalmente o significado das reivindicações por um tratamento justo e considerado de parte dos capatazes e chefias, torna-se fundamental colocar em primeiro plano a importância que os trabalhadores outorgavam a sua reputação, a sua respeitabilidade social e a suas responsabilidades enquanto provedores de suas famílias. Realmente,

48 LICHT, Walter. Working for the Railroad. The organization of work in the nineteenth century. Princeton: Princeton University Press, 1983. 
segundo as cartas e informes publicados no jornal da Federação, o fato de os trabalhadores ocuparem uma posição de subordinação na escala ocupacional e hierárquica não impedia que, enquanto homens dignos, fossem respeitados por suas chefias como iguais. O que estava em jogo era a democratização das relações trabalhistas, a equiparação dos homens que compartilhavam o mesmo âmbito de trabalho, independentemente de suas diferenças hierárquicas, nacionais, sociais ou de idade.

Pode-se concluir, por fim, que ao canalizar estas reclamações contra os abusos das chefias e privilegiar a defesa da honra masculina dos trabalhadores, a Federación Obrera Ferrocarrilera conseguiu reforçar sua identificação com os trabalhadores uma vez que fortaleceu sua unidade, pois priorizava o que os ferroviários tinham em comum enquanto homens, contornando assim as múltiplas diferenças que separavam esta população trabalhadora. É sabido que o caráter pioneiro da organização dos sindicatos ferroviários, sua força e capacidade de pressão freqüentemente são atribuídos ao seu peso numérico e ao caráter estratégico da atividade ferroviária na economia argentina, o que forçou as companhias e, também o estado, a reconhecer e negociar com estas organizações, contribuindo desta maneira para legitimar seu poder de representação. Além disso, sem rejeitar estes condicionantes estruturais, outros historiadores destacaram o papel das estratégias e práticas sindicais orientadas a criar um senso de comunidade para além das diferenças de ofícios e qualificações que existiam entre os trabalhadores ferroviários, como por meio da formação de cooperativas, bibliotecas e sociedades de ajuda mútua, entre outras. ${ }^{49}$ Neste estudo, acreditamos ter demonstrado que a ascendência da Federação se deve também a sua capacidade de assumir a defesa destes valores de respeitabilidade e honorabilidade masculinas e dos direitos e deveres do trabalhador interessado em cumprir

49 Charles Bergquist em Labor in Latin America (Stanford: Stanford University Press, 1986) privilegiou os fatores econômicos para explicar a capacidade de organização e negociação dos trabalhadores ferroviários. Por sua vez, Joel Horowitz destacou, contudo, a eficácia das formas de ação política dos dirigentes, cf. "Los trabajadores ferroviarios en la Argentina (1920-1943). La formación de una elite obrera", Desarrollo Económico, v. 25, n. 99(octubre-diciembre 1985). Os estudos monográficos sobre as origens dos sindicatos ferroviários na Argentina, em geral, combinam ambas variáveis, ver GOLBERG, Heidi. "Railroad Unionization in Argentina, 1912-1929. The Limitations of a Working Class Alliance", Yale University Ph. D., 1979; THOMPSON, Ruth. "Organized Labor in Argentina: The Railway Unions to 1922", D. Phil thesis (Oxford University , 1978) e GORDILLO, Mónica. El movimiento obrero ferroviario desde el interior del país (1916-1922) (Bs. As: CEAL, 1988). 
responsavelmente com suas obrigações familiares. Ao mesmo tempo em que este sindicato se convertia em porta-voz destes interesses de gênero com os quais muitos ferroviários se identificavam, requeria um compromisso dos trabalhadores com a organização e as lutas de seus irmãos proletários. Assim, à medida que as preocupações para com a dignidade masculina, os direitos e obrigações familiares do homem trabalhador se associavam à defesa da organização, a temática da honra, a respeitabilidade e os ideais da paternidade responsável se embebiam também das linguagens de classe, das representações e ideais das vanguardas militantes. 